\title{
The acquisition of spatial prepositions in Russian
}

Maria Grabovskaya

National Research University Higher School of Economics, Russian Federation

https://doi.org/10.36505/ExLing-2015/06/0005/000242

\begin{abstract}
In this work the acquisition of prepositions $v$ 'in', na 'on', $u$ 'near', pod 'under', nad 'above' and $z_{a}$ 'behind' was tested. Children between ages 3:0,6 and 7:1,9 were asked to describe everyday situations based on pictures (e.g. sobaka $v$ budke 'the dog in the kennel'). The results show that the prepositions $v$ 'in' and pod 'under' are acquired first, followed by the preposition na 'on'. Then the prepositions nad 'above' and za 'behind' are acquired.
\end{abstract}

Key words: Language acquisition; Spatial prepositions.

\section{Introduction}

In Russian both prepositions and cases are used to express the location of the object. In this work only the acquisition of prepositions is examined. Cases start to appear earlier than prepositions (Gvozdev 1961, Ufimceva 1979). After the appearance of cases "stopgaps" and "pseudoprepositions" (vowel sounds or real prepositions) begin to emerge (Berman 1985, Leikin 1989), although this stage is not found in the speech of every child (Leikin 1989). It is also important to mention that before prepositions children start using locative adverbs (Gvozdev 1961, Leikin 1989). The meaning of prepositions is understood in all the situations, not in the particular contexts (Clark 1973, Johnston 1988, Wilcox \& Palermo 1982).

In this article we are going to test the hypothesis of Leikin (1998), who studied the ability of Russian children between ages 3;0 and 7;2 to produce and understand locative expressions, and suggested that the acquisition of locative prepositions is not complete until approximately the age of 7 . Figure 1 represents the direction of substitutions in naming spatial relations established by Leikin based on experimental tasks that involve manipulation of geometrical objects. We look at prepositional use for more common situations of speech production.

ExLing 2015: Proceedings of 6th Tutorial and Research Workshop on Experimental Linguistics, 26-27 June 2015, Athens, Greece 


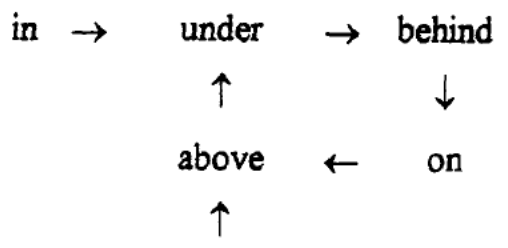

in front of
Figure 1. "Directions of substitutions in naming spatial relationships (most frequent types of substitutions)" (Leikin 1998).

\section{Method}

\section{Subjects}

Responses were elicited from 57 subjects between the ages of 3:0,6 and 7:1,9. 29 subjects from all the children were male, 28 subjects - female. For all the children Russian was a native language. 8 children were 3 years old, 9 children were 4 years old, 23 children were 5 years old, 16 children were 6 years old and there was 1 child who was 7 years old.

\section{Procedure}

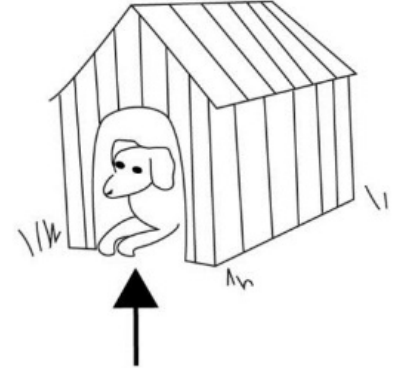

Picture 1. Sobaka v budke 'the dog in the kennel'

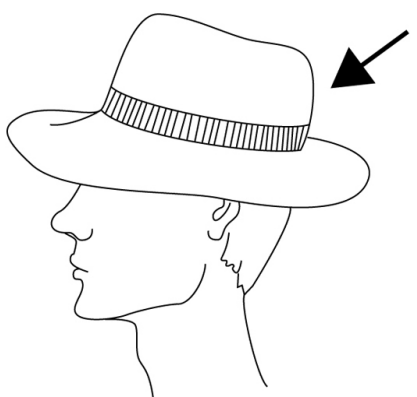

Picture 2. Shljapa na golove

'the hat on the head'

As stimuli, we have $24+4$ pictures from Topological relations picture series (Bowerman \& Pederson 1992) where 4 pictures were used for training. All the pictures depict everyday situations. Each picture was presented separately. From the main 24 pictures 2 pictures were supposed to provoke the preposition $v$ 'in' in the description of these pictures; 2 pictures were supposed to provoke the preposition pod 'under', 1 picture - the preposition $u$ 'near', 2 pictures - nad 'above', 17 pictures - na 'on'. There were more pictures for the last mentioned preposition because they hold different types of meaning. 
Compare the expected phrases: kniga na polke 'the book on the shelf, treshbina na chashke 'the crack on the cup', jabloko na jablone 'the apple on the apple-tree'. We analyzed the results for all the 24 pictures and 1 picture from 4 training pictures (that is supposed to provoke the preposition za 'behind'.

The order of the main 24 pictures was the same for all the children. The task for the children was to describe the picture starting with the object to which the arrow points. For example, for Picture 1 expected answer is sobaka $v$ budke 'the dog in the kennel', for Picture 2 - shljapa na golove 'the hat on the head'. Sometimes the interviewers used the hints to help a child (e.g. naming of the difficult object). The linguists didn't help children with the prepositions.

\section{Results}

The process of acquiring prepositions is not finished for all our subjects, which corresponds to the hypothesis of Leikin (1998). The prepositions $v$ 'in' and pod 'under' are acquired earlier and used correctly even by children of 3 years old, as predicted by Leikin (1998). The preposition na 'on' is acquired a bit later (approximately at the age of 4). The preposition $u$ 'near' appeared to have many synonyms (rjadom s, vozle, okolo) but this doesn't contradict its early acquisition but points at its low frequency. The prepositions nad 'above' and za 'behind' are acquired later. Moreover, nad 'above' seems to be acquired earlier than za 'behind'. Some stimuli appeared to be hard to describe despite the fact that the expected preposition was relatively basic (example: jabloko na strele 'the apple on the arrow'). This picture is often described in other ways - e.g. jabloko protknuto streloj 'the apple picked by the arrow'. The results of Gvozdev (1961) and Leikin (1989) were also proved: locative adverbs are acquired earlier than prepositions. A child tends to describe the picture with adverbs (for example, naverbu 'up', vnizu 'down') when he or she doesn't have the needed preposition acquired (smth is situated up and smth is situated down). Children also tend to replace some of the nouns that are part of the object on the object itself: e.g. replacement of jabloko na vetke 'the apple on the branch' on jabloko na dereve 'the apple on the tree'.

\section{Notes}

The children were asked by the author and a group of other linguists who also needed the data but for their own different work about other aspects of speech acquisition.

\section{Acknowledgements}

The author would like to thank Tatyana Nikitina for helpful advices during the work on this project. 


\section{References}

Berman, R. A. (1985). The acquisition of Hebrew. In D. Slobin (Ed.), The crosslinguistic Study of language acquisition, 255-371. New York: Erlbaum.

Bowerman, M., \& Pederson, E. 1992. Topological relations picture series. In S. C. Levinson (ed.), Space stimuli kit 1.2, 51. Nijmegen: Max Planck Institute for Psycholinguistics.

Clark, H. 1973. Space, time, semantics and the child. In T. Moore (ed.), Cognitive development and the acquisition of language, 27-64. New York: Academic Press.

Gvozdev, A. D. 1961. Voprosy izucheniya detskoy rechi [Problems of studying children's speech]. Moscow, Izdatelstvo Akademii Pedagogicheskikh Nauk RSFSR.

Johnston, J. J. 1988. Children's verbal representation of spatial location. In J. StilesDavis, M. Kritchevsky, \& U. Bellugi (eds.), Spatial cognition, 195-205. Hillsdale, NJ: Erlbaum.

Leikin, M. W. 1989. Puti logopedicekoj raboty po preodoleniu agrammatizmov v ponimanii i upotreblenii prostransivennykh predlogov u bolnykh $\mathrm{s}$ aphasiey [Speech therapy on prepositional agrammatism in aphasia]. Unpublished doctoral dissertation, Leningrad, Leningrad State, Pedagogical Institute.

Leikin, M. 1998. Acquisition of Locative Prepositions in Russian. Journal of Psycholinguistic Research 27, 91-108.

Ufimceva, N. V. 1979. Psikholingvisticheskie kharakteristiki funkcionirovanija kategorii padezha sushestvujushego v russkom jazyke [Psycholinguistic Issues of Grammar]. In F. Tarasov (ed.), Psikholingvisticheskie problemy grammatiki, 5-65. Moscow, Moscow University.

Wilcox, S. \& Palermo, D. 1982. Children's use of lexical and non-lexical information in responding to commands. Journal of Child Language, 9, 139-50. 